\section{Phytochemical screening, antinociceptive and anti-inflammatory activities of Chrysopogon zizanioides essential oil}

\author{
Gabrielle M. Lima, ${ }^{1}$ Lucindo J. Quintans-Júnior, ${ }^{1}$ Sara M. \\ Thomazzi, ${ }^{1}$ Emyle M. S. A. Almeida, ${ }^{1}$ Mônica S. Melo, ${ }^{1}$ Mairim \\ R. Serafini, ${ }^{1}$ Sócrates C. H. Cavalcanti, ${ }^{1}$ Daniel P. Gelain, ${ }^{5}$ João \\ Paulo A. Santos, ${ }^{5}$ Arie F. Blank, ${ }^{2}$ Péricles B. Alves, ${ }^{3}$ Paulina \\ M. Oliveira Neta, ${ }^{3}$ Julianeli T. Lima, ${ }^{4}$ Ricardo F. Rocha, ${ }^{5}$ José \\ ClaúdioF. Moreira, ${ }^{5}$ Adriano A. S. Araújo ${ }^{* 1,5}$
}

\author{
${ }^{1}$ Departamento de Fisiologia, Universidade Federal de Sergipe, Brazil, \\ ${ }^{2}$ Departamento de Agronomia, Universidade Federal de Sergipe, Brazil, \\ ${ }^{3}$ Departsmento de Química, Universidade Federal de Sergipe, Brazil, \\ ${ }^{4}$ Departamento de Ciências Farmacêuticas, Universidade Federal do Vale do São \\ Francisco, Brazil, \\ ${ }^{5}$ Departamento de Bioquímica, Universidade Federal do Rio Grande do Sul, \\ Brazil.
}

\begin{abstract}
Chrysopogon zizanioides (L.) Roberty, Poaceae, is a plant widely used in northeast Brazil in folk medicine for the treatment of various pathological conditions, including inflammatory pain. The present study evaluated the antinociceptive and antiinflammatory effects of $C$. zizanioides essential oil (EO) in rodents. EO was further characterized by GC/MS. The major components of EO were identified as khusimol (19.57\%), $E$-isovalencenol (13.24\%), $\alpha$-vetivone (5.25\%), $\beta$-vetivone $(4.87 \%)$ and hydroxy-valencene (4.64\%). Following intraperitoneal injection (i.p.), EO at 50 and $100 \mathrm{mg} / \mathrm{kg}$ significantly reduced the number of writhes (51.9 and $64.9 \%$, respectively) and the number of paw licks during phase 2 (56.7 and $86.2 \%$, respectively) of a formalin model when compared to control group animals. However, EO-treated mice were ineffective at all doses in hot-plate and rota-rod tests. The EO inhibited the carrageenan-induced leukocyte migration to the peritoneal cavity in a dose-dependent manner $(34.7,35.4$, and $62.5 \%$ at doses of 25,50 and $100 \mathrm{mg} / \mathrm{kg}$, respectively). In the paw edema test, the EO $(100 \mathrm{mg} / \mathrm{kg})$ inhibited all three phases of the edema equally well, suggesting that the EO has a non-selective inhibitory effect on the release or actions of these mediators. Our results suggest possible antinociceptive and antiinflammatory effects of the EO.
\end{abstract}

Revista Brasileira de Farmacognosia Brazilian Journal of Pharmacognosy 22(2): 443-450, Mar./Apr. 2012

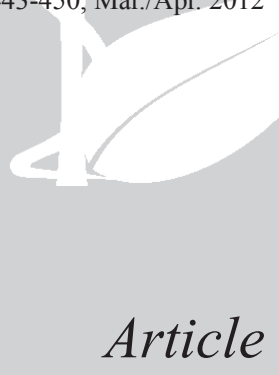

Received 16 May 2011

Accepted 18 Aug 2011

Available online 6 Jan 2012

Keywords: anti-inflammatory effect antinociceptive effect Chrysopogon zizanioides essential oil phytochemical screening vetiver

ISSN 0102-695X http://dx.doi.org/10.1590/S0102$695 \times 2012005000005$

\section{Introduction}

Medicinal plants are known as an important source of new chemical substances with potential therapeutic effects (Almeida et al., 2001). Recently, essential oils extracted from various herbs and spices have been a subject of intensive research, partially due to the continuous discoveries of their multifunctional properties other than their classical roles as food additives and/or fragrances. For example, antibacterial, antifungal, anticonvulsant, antinociceptive and anti-inflammatory activities of many essential oils have been investigated (Elisabetsky et al., 1995; Hammer et al., 1999; Almeida et al., 2001; Quintans-Junior et al., 2008).

Chrysopogon zizanioides Nash, Poaceae, popularly known as vetiver and "grama-das-índias", is one of the most important raw materials in perfumery (Martinez et al., 2004). The genus Vetiver has recently been reclassified (Adams et al., 1998), and is now combined with Chrysopogon (Veldkamp, 1999), based on their overlapping genetic and morphological data. This led to the recognition of $C$. zizanioides (L.) Roberty as the correct classification for Vetiveria zizanioides (L.) Nash (Massardo et al., 2006). Except for termiticidal (Maistrello et al., 2001) and antimicrobial activities (Hammer et al., 1999), the oil has not been studied intensively concerning other biological functionalities, probably because of its complex constituents. Vetiver oil is composed of more than 170 compounds that are mainly sesquiterpenes and their derivatives (Nigam et al., 1968; Weyerstahl et al., 2000b).

Despite the traditional use as analgesic 
and sedative in Brazil, no reports concerning the antinociceptive effects of vetiver are available. Besides, the properties of vetiver regarding free radicals and oxidative damage have never been studied. Considering the role of reactive oxygen species (ROS) in physiological and pathophysiological processes, and also considering that secondary metabolites have been observed to exert multiple roles in response to ROS-mediated insults when administered therapeutically or used in the diet, it is important to investigate redox-associated properties of compounds derived from natural sources. In this regard, we studied the antinociceptive and anti-inflamatory effects of essential oil of $C$. zizanioides in rodents, as well as some of its redox properties in vitro.

\section{Material and Methods}

\section{Plant material and essential oil (EO) extraction}

Roots were collected from the cultivation of Chrysopogon zizanioides (L.) Roberty, Poaceae, genotypes established at the Research Farm "Campus Rural da UFS" of the Federal University of Sergipe, Brazil, and a voucher sample has been deposited in the Herbarium of the Department of Biology, Federal University of Sergipe (ASE 13437). The roots of $C$. zizanioides were oven dried with air renewal and circulation (model MA-037/18) at $40{ }^{\circ} \mathrm{C}$ until complete dehydration has been achieved. The essential oil (EO) was obtained by hydrodistillation in a Clevenger-type apparatus using $250 \mathrm{~g}$ of dried roots. The essential oil (EO) obtained was dried over anhydrous sodium sulfate, producing yields of $4.15 \%(\mathrm{v} / \mathrm{w})$.

\section{Analysis of the essential oil by GC/MS}

A Shimadzu system (Kyoto, Japan), consisting of a QP-5050A mass spectrometer equipped with a GC17A gas chromatograph with a Shimadzu AOC 20i autoinjector and a split (ratio 1:83) injector was used for the identification and quantification of the EO studied. A fused silica column DB-5MS (30 m x $0.25 \mathrm{~mm}$ i.d, composed of $5 \%$ phenylmethylpolysiloxane), supplied by J\&W Scientific (Folsom, CA, USA), was employed, with helium (99.999\% purity) as carrier gas at a flow-rate of $1.2 \mathrm{~mL} / \mathrm{min}$. The column temperature was programmed as follows: $50{ }^{\circ} \mathrm{C}$ for $1.5 \mathrm{~min}$, then directly to $200{ }^{\circ} \mathrm{C}$ at 4 ${ }^{\circ} \mathrm{C} / \mathrm{min}$, them $10{ }^{\circ} \mathrm{C} / \mathrm{min}$ to $300^{\circ} \mathrm{C}$, ending with a $10 \mathrm{~min}$ isothermal at $300{ }^{\circ} \mathrm{C}$. The injector port was maintained at $250{ }^{\circ} \mathrm{C}$, ion-source temperature $280{ }^{\circ} \mathrm{C}$ and $0.5 \mathrm{~L}$ sample volumes were injected. The mass spectra were taken at $70 \mathrm{eV}$ with scanning speed of $0.85 \mathrm{scan} / \mathrm{s}$ from 40 to 550 $\mathrm{Da}$. The data were acquired and processed with a PC with Shimadzu Class-5000 software. The identification of the constituents was assigned on basis of comparison of their relative retention indices (Van Den Dool \& Kratz, 1963) to a $n$-alkane homologous series (nC9-nC18) obtained by coinjecting the oil sample with a linear hydrocarbon mixture, as well as, by computerized matching of the acquired mass spectra witch those stored in NIST21 and NIST107 mass spectral libraries of the GC/MS data system and other published mass spectra (Adams, 2007; Adams et al., 2008).

Animals

Male Swiss mice weighing 25-35 g, maintained under standard environmental conditions, were used distributed in groups of ten (writhing, formalin, hot-plate and rota-rod tests) and six male Wistar rats weighing 150$180 \mathrm{~g}$ each (neutrophil migration activity and carrageenaninduced hind paw edema). The animals were randomly housed in appropriate cages at $22 \pm 1{ }^{\circ} \mathrm{C}$ on a $12 \mathrm{~h}$ light/ dark cycle (lights on 6 am to $6 \mathrm{pm}$ ) with free access to food and water. Experimental protocols and procedures were approved by the Federal University of Sergipe Animal Care and Use Committee (CEPA/UFS 23/08).

\section{Acetic acid-induced writhing}

In this model (Koster et al., 1959), groups of mice were administered $0.85 \%$ acetic acid $(10 \mathrm{~mL} / \mathrm{kg}$ body wt., i.p.), and the number of abdominal contractions was registered over $20 \mathrm{~min}$, starting $5 \mathrm{~min}$ after acetic acid injection. Animals ( $\mathrm{n}=10$, per group) were treated intraperitoneally (i.p.) with EO $(25,50$, and $100 \mathrm{mg} / \mathrm{kg}$ ), 30 min before acetic acid administration. Distilled water with one drop of tween $800.2 \%$ (vehicle) was used i.p. in control animals. The effect of pretreatment with naloxone (NAL, $1.5 \mathrm{mg} / \mathrm{kg}$, i.p.) on the antinociception produced by EO (50 and $100 \mathrm{mg} / \mathrm{kg}$ ) and morphine (MOR, $3.0 \mathrm{mg} / \mathrm{kg}$, i.p.) was determined.

\section{Formalin test}

The formalin test was carried out as described by Hunskaar et al. (1985). The animals were separated into five groups $(\mathrm{n}=10$, per group) and treated i.p. with vehicle (control), EO $(25,50$, and $100 \mathrm{mg} / \mathrm{kg})$ and aspirin (200 $\mathrm{mg} / \mathrm{kg}$ ). After $30 \mathrm{~min}, 20 \mu \mathrm{L}$ of $2.5 \%$ formalin solution $(0.92 \%$ formaldehyde in $0.9 \%$ saline) was injected into the subplantar area of the right hindpaw. The duration of paw licking was measured at 0-5 min (first phase) and 15-30 min (second phase) after formalin administration (Hunskaar \& Hole, 1987).

\section{Hot-plate test}

The hot-plate test measured response latencies according to the method described by Eddy \& Leimback 
(1953). Animals were placed on an Insight ${ }^{\circledR}$ hot-plate (Model EFF-361) maintained at $55 \pm 1{ }^{\circ} \mathrm{C}$ and the time between placement of the animal on the hot-plate and the occurrence of either the licking of the hind paws, shaking or jump off from the surface was recorded as response latency. Mice with baseline latencies of more than $10 \mathrm{~s}$ were eliminated from the study $24 \mathrm{~h}$ later. The cut-off time for the hot plate latencies was set at $30 \mathrm{~s}$. Animals $(\mathrm{n}=10$, per group) were treated with $\mathrm{EO}(25,50$, and $100 \mathrm{mg}$ / $\mathrm{kg}$, i.p.) $30 \mathrm{~min}$ before the experiments. Animals control received the same treatment to abdominal constriction test.

\section{Rota-rod test}

Mice able to remain on the Rota-rod apparatus (AVS ${ }^{\circledR}$, Brazil) longer than $180 \mathrm{~s}(9 \mathrm{rpm})$ were selected 24 $\mathrm{h}$ before the test according to Gonçalves et al. (2008). Then the selected animals were divided into five groups $(n=8)$ and treated i.p. with vehicle (control), EO (25, 50, and 100 $\mathrm{mg} / \mathrm{kg})$, and diazepam $(1.5 \mathrm{mg} / \mathrm{kg})$. Thirty minutes later, each animal was tested on the Rota-rod and the time (s) they remained on the bar for up to $180 \mathrm{~s}$ was recorded.

\section{Carrageenin-induced hind paw edema in rats}

The acute hind paw edema was produced by injecting $0.1 \mathrm{~mL}$ of carrageenan (prepared as $1 \%$ suspension in sterile normal saline) locally into the plantar aponeurosis of the right hind paw of rats (Winter et al., 1962). EO (50, 100, and $200 \mathrm{mg} / \mathrm{kg}$, i.p. ) was administered to three different groups while the other two groups served as negative and positive controls and received vehicle and standard drug, Aspirin (300 mg/kg, p.o.), respectively. EO and aspirin were administered $1 \mathrm{~h}$ prior to the injection of carrageenan. The rat pedal volume up to the ankle joint was measured using plethysmometer (Model LE 7500 Panlab, Barcelona, Spain) at 0 (just before) and $3 \mathrm{~h}$ after the injection of carrageenan.

\section{Leukocyte migration to the peritoneal cavity}

The leukocyte migration was induced by injection of carrageenan $(500 \mu \mathrm{g} /$ cavity, i.p., $500 \mu \mathrm{L})$ into the peritoneal cavity of rats $30 \mathrm{~min}$ after administration of EO $(25,50$, and $100 \mathrm{mg} / \mathrm{kg}$, i.p.) or dexamethasone (2 mg/ $\mathrm{kg}$, s.c., $\mathrm{n}=6$ ) by modification of the technique previously described by Bastos et al. (2007). The animals were euthanized by cervical dislocation $4 \mathrm{~h}$ after carrageenan injection. Shortly after, phosphate buffered saline (PBS) containing EDTA (1 mM, i.p., $10 \mathrm{~mL})$ was injected. Immediately a brief massage was done for further fluid collection, which was centrifuged (2000 rpm, $5 \mathrm{~min}$ ) at room temperature. The supernatant was disposed of 1 $\mathrm{mL}$ of PBS was introduced to the precipitate. An aliquot of $10 \mu \mathrm{L}$ from this suspension was dissolved in $200 \mu \mathrm{L}$ of Turk solution and the total cells were counted in a Neubauer chamber, under optic microscopy. The results were expressed as the number of neutrophils $/ \mathrm{mL}$. The percentage of the leukocyte inhibition $=(1-\mathrm{T} / \mathrm{C}) \times 100$, where $\mathrm{T}$ represents the treated groups leukocyte counts and $\mathrm{C}$ represents the control group leukocyte counts.

\section{TBARS Assay}

TBARS (thiobarbituric acid reactive species) assay was employed to measure the antioxidant capacity of EO using egg yolk homogenate as lipid rich substrate. Briefly, egg yolk was homogenized $(1 \% \mathrm{w} / \mathrm{v})$ in $20 \mathrm{mM}$ phosphate buffer ( $\mathrm{pH} 7.4), 1 \mathrm{~mL}$ of homogenate was sonicated (10 s in potency 4$)$ and then homogenized with $0.1 \mathrm{~mL}$ of $\mathrm{EO}$ at different concentrations or controls in different concentrations prepared immediately before use. Lipid peroxidation was induced by addition of $0.1 \mathrm{~mL}$ of (2,2'-azobis[2-methylpropionamidine]dihydrochloride) (AAPH, a free radical source) solution $(0.12 \mathrm{M})$. Trolox was used as reference antioxidant molecule, (positive control); negative control was only EO vehicle (DMSO $10 \%$ ). Reactions were carried out for $30 \mathrm{~min}$ at $37{ }^{\circ} \mathrm{C}$. After cooling, samples $(0.5 \mathrm{~mL})$ were centrifuged with 0.5 $\mathrm{mL}$ of trichloroacetic acid (15\%) at $1200 \mathrm{~g}$ for $10 \mathrm{~min}$. An aliquot of $0.5 \mathrm{~mL}$ from supernatant was mixed with $0.5 \mathrm{~mL}$ TBA $(0.67 \%)$ and heated at $95{ }^{\circ} \mathrm{C}$ for $30 \mathrm{~min}$. After cooling, samples absorbance was measured using a spectrophotometer at $532 \mathrm{~nm}$. The results were expressed as percentage of TBARS formed by AAPH alone (induced control) (Draper \& Hadley, 1990).

\section{Hydroxyl scavenging activity}

The formation of ${ }^{\circ} \mathrm{OH}$ (hydroxyl radical) from Fenton reaction was quantified using 2-deoxyribose oxidative degradation. The principle of the assay is the quantification of the 2-deoxyribose degradation product, Malondialdehyde (MDA), by its condensation with 2-thiobarbituric acid (TBA). Briefly, typical reactions were started by the addition of $\mathrm{Fe}^{2+}$ (6m M final concentration) to solutions containing $5 \mathrm{mM}$ 2-deoxyribose, $100 \mathrm{mM}$ $\mathrm{H}_{2} \mathrm{O}_{2}$ and $20 \mathrm{mM}$ phosphate buffer ( $\mathrm{pH}$ 7.2). To measure EO antioxidant activity against hydroxyl radical, different concentrations of EO were added to the system before $\mathrm{Fe}^{2+}$ addition. Reactions were carried out for $15 \mathrm{~min}$ at room temperature and were stopped by the addition of $4 \%$ phosphoric acid (v/v) followed by $1 \%$ TBA (w/v, in $50 \mathrm{mM} \mathrm{NaOH}$ ). Solutions were boiled for $15 \mathrm{~min}$ at 95 ${ }^{\circ} \mathrm{C}$, then cooled at room temperature. The absorbance was measured at $532 \mathrm{~nm}$ and results were expressed as MDA equivalents formed by $\mathrm{Fe}^{2+}$ and $\mathrm{H}_{2} \mathrm{O}_{2}$ (Payá et al., 1994). 


\section{Statistical analysis}

The data obtained were evaluated by one-way analysis of variance (ANOVA) followed by Dunnett's or Fisher's tests. Differences were considered to be statistically significant when $p<0.05$. The percent of antinociceptive inhibition was evaluated for each experimental group using the following formula (Reanmongkol et al., 1994): Inhibition $\%=100 \times$ (control-experiment)/control.

\section{Results}

Analysis of the essential oil by GC/MS

GC-MS analysis showed a mixture of compounds, with khusimol (19.57\%), E-isovalencenol (13.24\%), $\alpha$-vetivone $(5.25 \%)$, vetiselinenol $(5.08 \%), \alpha$-cadinol $(5.01 \%), \alpha$-vetivone $(4.87 \%)$ and hydroxy-valencene (4.64\%) as the major compounds in the EO (Table 1).

The analysis of the vetiver oil showed the presence mainly the tricyclic sesquiterpene khusimol, and the bicyclic sesquiterpenes $(E)$-isovalencenol. Some species showed variable oil composition, these differences often separate them into several chemotypes. The biosynthesis of secondary metabolites, although controlled genetically, is strongly affected by environmental, harvest and post-harvest factors. Agricultural factors have a critical effect on quantitative and qualitative characteristics of some Poaceae (such as citronella or vetiver oils), which affect plant growth and yield. Kim et al. (2005) and Massardo et al. (2006) found a large variation on volatile oil yield and content depending on seasonal changes and harvesting time. This variability of metabolism causes changes in the biological effect of essential oil and in concentration of the mainly compounds (Oliveira et al., 2009). Massardo reported that the major components in vetiver essential oil were identified as $(E)$-isovalencenol (19.5 to $25.0 \%$ ), khusimol (11.1 to $12.9 \%$ ) and zizanoic acid (4.4 to $5.7 \%)$. These authors reported that vetiver essential oil production is closely related to the metabolism of plant, which is affected by changes in environmental temperatures.

\section{Pharmacological assays}

In the acetic acid-induced writhing test, the antinociceptive effect, represented by writhe reduction, elicited by 50 and $100 \mathrm{mg} / \mathrm{kg}$ of EO $(6.3 \pm 1.6$ and $4.6 \pm 2.0)$ in mice was similar to that of morphine $3 \mathrm{mg} / \mathrm{kg}(0.7 \pm 0.2)$, a standard opioid drug, when both groups were compared with control $(13.1 \pm 2.1)$. EO in dose of $25 \mathrm{mg} / \mathrm{kg}$ did not produce any significant effect (Table 2).

It was observed that naloxone $(1.5 \mathrm{mg} / \mathrm{kg}$, i.p. $)$ antagonized the antinociceptive response of morphine from $0.7 \pm 0.2$ (with vehicle only) to $11.8 \pm 2.4$ (with vehicle plus naloxone) writhes in the acetic acid-induced writhing test. Naloxone $(1.5 \mathrm{mg} / \mathrm{kg}$, i.p.) partially reversed the antinociceptive effect of the EO $(100 \mathrm{mg} / \mathrm{kg}$, i.p.) (Table 2).

Table 1. Essential oil composition of Chrysopogon zizanioides.

\begin{tabular}{|c|c|c|c|}
\hline $\mathrm{RT}(\min )^{\mathrm{a}}$ & Compounds $^{\mathrm{b}}$ & $(\%)$ & $\mathrm{IK}^{\mathrm{c}}$ \\
\hline 25.017 & prezizaene & 0.15 & 1444 \\
\hline 25.167 & khusimene & 0.19 & 1455 \\
\hline 25.925 & $\gamma$-gurjunene & 0.66 & 1478 \\
\hline 26.242 & $\beta$-vetispirene & 0.32 & 1488 \\
\hline 26.350 & $\gamma$-amorphene & 0.11 & 1491 \\
\hline 28.125 & elemol & 0.18 & 1547 \\
\hline 28.283 & $\beta$-vetivenene & 0.13 & 1552 \\
\hline 28.583 & maaliol & 1.60 & 1562 \\
\hline 29.525 & viridiflorol & 0.34 & 1592 \\
\hline 29.900 & khusimone & 1.09 & 1605 \\
\hline 30.000 & $\beta$-atlantol & 0.46 & 1608 \\
\hline 30.417 & junenol & 3.58 & 1622 \\
\hline 30.708 & 10-epi- $\gamma$-eudesmol & 0.54 & 1632 \\
\hline 30.758 & cubenol & 0.77 & 1634 \\
\hline 31.042 & 1,7-diepi- $\alpha$-cedrenal & 0.38 & 1643 \\
\hline 31.375 & $\alpha$-cadinol & 5.01 & 1654 \\
\hline 31.825 & mustakone & 2.75 & 1669 \\
\hline 32.050 & 2-epi-ziza-6(13)-em-3-ol & 2.79 & 1677 \\
\hline 32.658 & junicedranol & 1.90 & 1697 \\
\hline 33.083 & nootkatol & 0.53 & 1712 \\
\hline 33.383 & vetiselinenol & 5.08 & 1723 \\
\hline 33.567 & $(Z)$ - $\beta$-curcumen-12-ol & 1.50 & 1730 \\
\hline 33.875 & hydroxy-valencene & 4.64 & 1740 \\
\hline 34.058 & khusimol & 19.57 & 1747 \\
\hline 35.150 & $(E)$-isovalencenol & 13.24 & 1786 \\
\hline 35.267 & spirovetiva-3,7-(11)-dien-12-ol & 2.06 & 1790 \\
\hline 35.608 & nootkatone & 1.57 & 1801 \\
\hline 35.642 & vetivenic acid & 1.64 & 1803 \\
\hline 35.858 & $\beta$-vetivone & 4.87 & 1808 \\
\hline \multirow[t]{2}{*}{36.558} & $\alpha$-vetivone & 5.25 & 1825 \\
\hline & Total identified & 82.90 & \\
\hline
\end{tabular}

a Retention time; ${ }^{\mathrm{b} C o m p o u n d s ~ l i s t e d ~ i n ~ o r d e r ~ o f ~ e l u t i o n ~ f r o m ~ a n ~ D B-5 M S ~}$ column; 'Kovats indices were calculated against $n$-alkanes $\left(\mathrm{C}_{9}-\mathrm{C}_{18}\right)$ on a DB-5MS column; NI: Not Identified

EO inhibited the licking response to the injected paw when $50 \mathrm{mg} / \mathrm{kg}(62.3 \pm 23.7 \mathrm{~s})$ and $100 \mathrm{mg} / \mathrm{kg}$ $(19.9 \pm 7.4 \mathrm{~s})$ were administered i.p. in mice compared with the control group $(144.0 \pm 20.2 \mathrm{~s})$ in the second phase of the formalin test. However, EO or aspirin did not inhibit the licking response in first phase of the formalin test (Table $3)$.

Moreover, the hot plate test evaluated a possible 
central antinociceptive effect of the EO since this is considered a specific test for central pain analysis. EO did not interfere with nociception in this test (data not shown).

In the rota-rod test, EO-treated mice did not show any significant motor performance alterations with the doses of 50,100, or $200 \mathrm{mg} / \mathrm{kg}$ (data no shown). As might be expected, the CNS depressant diazepam $(1.5 \mathrm{mg} / \mathrm{kg})$ reduced the time of treated animals on the Rota-rod after $30 \mathrm{~min}(54.8 \pm 19.0)$ of treatment with this standard drug.

Table 4 shows that EO, in higher dose, inhibited all three phases $(52.8,39.1$, and $39.7 \%$ at dose $100 \mathrm{mg} / \mathrm{kg}$ ) of the carrageenan-induced rat paw edema equally well, suggesting that the EO has a non-selective inhibitory effect on the release or actions of these mediators.

Table 2. Effect of EO or morphine on writhing induced by acetic acid.

\begin{tabular}{lccc}
\hline Treatment & Dose (mg/kg) & $\begin{array}{c}\text { Number of } \\
\text { writhings }^{\mathrm{a}}\end{array}$ & Inhibition (\%) \\
\hline Vehicle & - & $13.1 \pm 2.1$ & - \\
EO & 25 & $11.3 \pm 1.9$ & 13.7 \\
EO & 50 & $6.3 \pm 1.6 \mathrm{~b}$ & $51.9^{\mathrm{e}}$ \\
EO & 100 & $4.6 \pm 2.0 \mathrm{c}$ & $64.9^{\mathrm{e}}$ \\
EO+NAL & $100+1.5$ & $10.7 \pm 2.8$ & 18.3 \\
MOR & 3 & $0.7 \pm 0.2 \mathrm{~d}$ & $94.7^{\mathrm{f}}$ \\
MOR+NAL & $3+1.5$ & $11.8 \pm 2.4$ & 9.9 \\
\hline
\end{tabular}

NAL: naloxone; MOR: morphine; $\mathrm{n}=10$; ${ }^{\text {V Values represent mean } \pm \mathrm{SEM}}$ ${ }^{\mathrm{b}} p<0.05,{ }^{\mathrm{c}} p<0.01$ and ${ }^{\mathrm{d}} p<0.001$ (ANOVA and Dunnett's test), significantly different from control; ${ }^{\mathrm{e}} p<0.01$ and ${ }^{\mathrm{f}} p<0.001$ (Fisher’s test), significantly different from control.

Table 3. Effect of EO or aspirin on formalin-induced pain.

\begin{tabular}{|c|c|c|c|c|c|}
\hline \multirow{3}{*}{ Treatment } & \multirow{3}{*}{ Dose (mg/kg) } & \multicolumn{4}{|c|}{ Number of licks (s) } \\
\hline & & \multicolumn{2}{|c|}{$0-5 \min$} & \multicolumn{2}{|c|}{$15-30 \mathrm{~min}$} \\
\hline & & Score of pain ${ }^{\mathrm{a}}$ & Inhibition (\%) & Score of pain ${ }^{\mathrm{a}}$ & Inhibition (\%) \\
\hline Vehicle & - & $48.4 \pm 4.3$ & - & $144.0 \pm 20.2$ & - \\
\hline EO & 25 & $40.9 \pm 3.9$ & 15.5 & $98.6 \pm 25.6^{b}$ & $31.5^{\mathrm{d}}$ \\
\hline EO & 50 & $37.1 \pm 4.6$ & 23.3 & $62.3 \pm 23.7^{\mathrm{b}}$ & $56.7^{\mathrm{e}}$ \\
\hline EO & 100 & $38.9 \pm 6.7$ & 19.6 & $19.9 \pm 7.4^{\mathrm{c}}$ & $86.2^{\mathrm{f}}$ \\
\hline Aspirin & 200 & $41.4 \pm 9.7$ & 14.5 & $45.9 \pm 29.6^{\mathrm{b}}$ & $68.1^{\mathrm{e}}$ \\
\hline
\end{tabular}

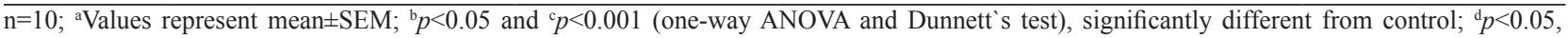
${ }^{\mathrm{e}} p<0.01$ and ${ }^{\mathrm{f}} p<0.001$ (Fisher's test), significantly different from control.

Table 4. Inhibitory effect of EO or aspirin on carrageenan-induced paw edema in rats.

\begin{tabular}{lccccccc}
\hline \multirow{2}{*}{ Treatment } & \multirow{2}{*}{ Dose $(\mathrm{mg} / \mathrm{kg})$} & \multicolumn{3}{c}{ Paw volume increase $(\mathrm{mL})^{\mathrm{a}}$} & \multicolumn{3}{c}{ Inhibition (\%) } \\
\cline { 3 - 7 } & & $1 \mathrm{~h}$ & $2 \mathrm{~h}$ & $3 \mathrm{~h}$ & $1 \mathrm{~h}$ & $2 \mathrm{~h}$ & $3 \mathrm{~h}$ \\
\hline Vehicle & - & $0.36 \pm 0.07$ & $0.69 \pm 0.11$ & $0.73 \pm 0.10$ & - & - & - \\
EO & 25 & $0.29 \pm 0.10$ & $0.71 \pm 0.07$ & $0.65 \pm 0.09$ & 14.4 & -2.9 & 11.0 \\
EO & 50 & $0.31 \pm 0.08$ & $0.59 \pm 0,15$ & $0.58 \pm 0.09$ & 13.9 & 14.5 & 20.6 \\
EO & 100 & $0.17 \pm 0.03^{\mathrm{b}}$ & $0.42 \pm 0.04^{\mathrm{b}}$ & $0.44 \pm 0.02^{\mathrm{c}}$ & $52.8^{\mathrm{e}}$ & $39.1^{\mathrm{d}}$ & $39.7^{\mathrm{d}}$ \\
Aspirin & 300 & $0.09 \pm 0.03^{\mathrm{c}}$ & $0.28 \pm 0.02^{\mathrm{c}}$ & $0.39 \pm 0.03^{\mathrm{c}}$ & $75.0^{\mathrm{e}}$ & $59.4^{\mathrm{e}}$ & $46.6^{\mathrm{d}}$ \\
\hline
\end{tabular}

$\mathrm{n}=6$, per group; ${ }^{\mathrm{a} V a l u e s}$ represent mean $\pm \mathrm{SEM} ;{ }^{\mathrm{b}} p<0.01$ and ${ }^{\mathrm{c}} p<0.001$ (one-way ANOVA and Dunnett's test), significantly different from control; ${ }^{\mathrm{d}} p<0.05$ and ${ }^{\mathrm{e}} p<0.01$ (Fisher's test), significantly different from control. 
not prevent 2-deoxyribose degradation by a hydroxylgenerating system at any tested doses. However, at the concentration of $1 \mathrm{mg} / \mathrm{mL}$, EO enhanced hydroxylmediated 2-deoxyribose degradation.

\section{Discussion}

Chrysopogon zizanioides (L.) Roberty, Poaceae, is one of the most important raw materials in perfumery and has been used in folk medicine for the treatment of inflammatory pain in Brazilian Northeast (oral communication) (Lima, 2010). The main goal of this study was to evaluate the phythochemical screening, antinociceptive and anti-inflammatory activities of $C$. zizanioides essential oil (EO) in rodents.

GC-MS analysis of C. zizanioides EO exhibited a mixture of compounds similarly to a previous study of Weyerstahl et al. (2000a,b), Kim et al. (2005) and Adams et al. (2008). Among the odorous components in vetiver oils from different sources, khusimol, $E$-isovalencenol, $\alpha$-vetivone, vetiselinenol, $\alpha$-cadinol and are the major constituents, and their presence is often considered as the fingerprint of the oil.

The first test used for pharmacological evaluation was the writhing test. Past studies have postulated that the acetic acid acts indirectly by inducing the release of endogenous mediators which stimulate the nociceptive neurons sensitive to nonsteroidal anti-inflammatory drugs (NSAIDs) and opioids (Fischer et al., 2008). Although abdominal writhing induced by acetic acid represents a peripheral nociception model (Wei et al., 1986) and is normally used for screening synthetic and natural compounds, this is not a specific model, since several compounds, including opioid analgesics (Gomes et al., 2005) tricyclic antidepressants (Carter \& Sullivan, 2002) and antihistaminic compounds (Koster et al., 1959) inhibit acetic acid induced writhing. Based in our result, it can be assumed that the mode of action of this activity might involve a peripheral mechanism.

The formalin test has an advantage over other frequently used tests as it involves a biphasic response with an early and a late phase representing neurogenic and inflammatory pain and agents can be screened for activity in these two models of pain (Hunskaar and Hole, 1987). Neither EO or aspirin $(200 \mathrm{mg} / \mathrm{kg})$ decreased the paw licking time during the neurogenic (0-5 min) phase 1. However, the inflammatory phase (late phase) was significantly inhibited by aspirin and by EO. Moreover, the hot plate test checked a possible central antinociceptive effect of the EO since this is considered a specific test for central pain analysis. EO did not interfere with nociception in this test (data not shown).

Previous studies suggested that the CNS depression and the nonspecific muscle relaxation effect can reduce the response of motor coordination and consequently might invalidate the nociceptive behavioral tests results (Gonçalves et al., 2008). We did not see any interference with the motor coordination of the animals in the rota-rod test, therefore eliminating a nonspecific muscle relaxation effect of EO at the doses used. Various mediators are released by carrageenan in the rat paw. Thus, while the initial phase may be due to the release of histamine and serotonin, kinins may play a role in the middle phase (Di Rosa and Sorrentino, 1968) and prostaglandins could be the most important mediators in the final 3-5 h postcarrageenan response (Vinegar et al. 1969).

Corroborating the relevant anti-inflammatory activity of EO, we observed that the leukocyte migration to peritoneal cavity was strongly reduced by the all doses of EO. According to Bradley et al. (1982) the cell migration inhibition in models of inflammation has been considerated a convincing indicator of anti-inflammatory activity. The ability of the EO, in this study, to suppress abdominal writhes, inhibit the second phase of formalin induced pain as well as suppress the carrageenan- induced inflammation confirms the analgesic and anti-inflammatory activities of the EO.

The lipoperoxidation and hydroxyl-scavenging activity assays showed that EO does not act as an antioxidant, since EO was not able to prevent the lipoperoxidation damage to an lipid enriched system where a free radical source (AAPH) is added; besides, EO was also ineffective in prevent the degradation of 2-deoxyribose by hydroxyl radicals generated in vitro through Fenton reaction. As a matter of fact, the highest concentration of EO tested further enhanced the damage caused by hydroxyl. Altogether these results indicate that the effects of EO observed in this and other studies are nor mediated by free radicals or by a possible antioxidant activity.

Based on our results it is possible to conclude that EO has potential antinociceptive and anti-inflammatory activities, which might involve a peripheral mechanism, such as, inhibiting the synthesis or action of prostaglandins. However, further studies will enable as to understand the precise action mechanisms and toxicity of this plant.

Furthermore, some studies attribute the antiinflammatory activity of vetiver oil to its secondary metabolites, such as khusimol, $E$-isovalencenol, $\alpha$-vetivone, vetiselinenol, $\alpha$-cadinol and $\beta$-vetivone (Hammer et al., 1999; Güllüce et al., 2003).

\section{Acknowledgements}

We thank Mr Rangel R. Bonfim for the technical support. This work was supported by grants from Conselho Nacional de Desenvolvimento Científico e Tecnológico/ Brazil) and the Fundação de Amparo à Pesquisa do Estado de Sergipe. 


\section{References}

Adams RP, Zhong M, Turuspekov Y, Dafforn MR, Veldkamp JF 1998. DNA fingerprinting reveals clonal nature of Vetiveria zizanioides (L.) Nash, Gramineae and sources of potential new germoplasm. Mol Ecol 7: 813-818.

Adams RP 2007. Identification of Essential Oil Components by Gas Chromatography/Mass Spectroscopy. 4. ed. USA: Allured Publishing Corporation Carol Stream, IL.

Adams RP, Nguyen S, Johnston, DA, Park S, Provin TL, Habte M 2008. Comparation of vetiver root essential oils from cleansed (bacteria - and fungus-free) vs. non-cleansed (normal) vetiver plants. Biochem Syst Ecol 36: 177-182.

Almeida RN, Navarro DS, Barbosa-Filho JM 2001. Plants with central analgesic activity. Phytomedicine 8: 310-322.

Bastos LF, Merlo LA, Rocha LT, Coelho MM 2007. Characterization of the antinociceptive and antiinflammatory activities of doxycycline and minocycline in different experimental models. Eur J Pharmacol 576: 171-179.

Bradley PP, Priebat DA, Christensen RD, Rothstein G 1982. Measurement of cutaneous inflammation: estimation of neutrophil content with an enzyme marker. $J$ Invest Dermatol 78: 206-209.

Carter GT, Sullivan MD 2002. Antidepressants in pain management. Curr Opin Invest Dr 3: 454-458.

Di Rosa M, Sorrentino L 1968. The mechanism of the inflammatory effect of carrageenan. Eur J Pharmacol 4: 340-342.

Draper HH, Hadley M 1990. Malondialdehyde determination as index of lipid peroxidation. Meth Enzymol 186: 421431.

Eddy NB, Leimbach D 1953. Synthetic analgesic. II. Dithienylbutenyl and dithienylbutyl amines. $J$ Pharmacol Exp Ther 107: 385-393.

Elisabetsky E, Coelho-De-Souza GP, Santos MAC, Siqueira IR, Amador TA 1995. Sedative properties of linalool. Fitoterapia 66: 407-414.

Fischer LG, Santos D, Serafin C, Malheiros A, Delle Monache F, Delle Monache G, Cechinel V-Filho, Souza MM 2008. Further Antinociceptive properties of extracts and phenolic compounds from Plinia glomerata (Myrtaceae) leaves. Biol Pharm Bull 31: 235-239.

Gomes PB, Oliveira MM, Nogueira CR, Noronha EC, Carneiro LM, Bezerra JN, Neto MA, Vasconcelos SM, Fonteles MM, Viana GS, de Sousa FC 2005. Study of antinoceptive effect of isolated fractions from Petiveria alliacea L. (tipi) in mice. Biol Pharm Bull 28: 42-46.

Gonçalves JCR, Oliveira FS, Benedito RB, De Sousa DP, Almeida RN, Araújo DAM, 2008. Antinociceptive activity of (-)-carvone: evidence of association with decreased peripheral nerve excitability. Biol Pharm Bull 31: 1017-1020

Güllüce M, Sökmen M, Daferera D, Aar G, Özkan H, Kartal N, Polissiou M, Sökmen A, Ahin F S 2003. In vitro antibacterial, antifungal, and antioxidant activities of the essential oil and methanol extracts of herbal parts and callus cultures of Satureja hortensis L. J Agr Food Chem 51: 3958-3965.

Hammer KA, Carson CF, Riley TV 1999. Antimicrobial activity of essential oils and other plant extracts. J Appl Microbiol 86: 985-990.

Hunskaar S, Fasmer OB, Hole, K 1985. Formalin test in mice, a useful technique for evaluating mild analgesics. $J$ Neurosci Meth 14: 69-76.

Hunskaar S, Hole K 1987. The formalin test in mice: dissociation between inflammatory and noninflammatory pain. Pain 30: 103-114.

Kim HJ, Chen F, Wang X, Chung HY, Jin Z 2005. Evaluation of antioxidant activity of vetiver (Vetiveria zizanioides L.) oil and identification of Its antioxidant constituents. J Agr Food Chem 53: 7691-7695.

Koster R, Anderson M, de Beer J 1959. Acetic acid analgesic screening. Fed. Proc 18: 412-417.

Lima GM 2010. Avaliação pré-clínica do óleo essencial de Chrysopogon zizanioides (L.) Roberty (Poaceae). Dissertação de Mestrado em Ciências da Saúde, Universidade Federal de Sergipe, pp. 80.

Maistrello L, Henderson G, Laine R 2001. Efficacy of vetiver oil and nootkatone as soil barriers against Formosan subterranean termite (Isoptera: Rhinotermitidae). J Econ Entomol 94: 1532-1537.

Martinez J, Rosa PT, Menut C, Leydet A, Brat P, Pallet D, Meireles MA 2004. Valorization of Brazilian veiver (Vetiveria zizanioides L. Nahs ex Samll) oil. J Agr Food Chem 52: 6578-6584.

Massardo DR, Senatore F, Alifano P, Del Giudice L, Pontieri P 2006. Vetiver oil production correlates with early root growth. Biochem Syst Ecol 34: 376-382.

Nigam IC, Radecka C, Komae H 1968. Essential oils and their constitutents. XXXVII. Isolation and structure of khusenol, a new sesquiterpenic primary alcohol from oil of vetiver. J Pharm Sci 57: 1029-1030.

Oliveira JS, Porto LA, Estevam CS, Siqueira RS, Alves PB, Niculau ES, Blank AF, Almeida RN, Marchioro M, Quintans-Júnior LJ 2009. Phytochemical screening and anticonvulsant property of Ocimum basilicum leaf essential oil. Boletín Latinoamericano y del Caribe de Plantas Medicinales y Aromáticas 8: 195-202.

Payá M, Halliwell B, Hoult JRS 1994. Interactions of a series of coumarins with reactive oxygen species. Scavenging of superoxide, hypochlorous acid and hydroxyl radicals. Biochem Pharmacol 44: 205-214.

Quintans-Júnior LJ, Souza TT, Leite BS, Lessa NMN, Bonjardim LR, Santos MRV, Alves PB, Blank AF, Antoniolli AR 2008. Phythochemical screening and anticonvulsant activity of Cymbopogon winterianus Jowitt (Poaceae) leaf essential oil in rodents. Phytomedicine 15: 619-624.

Reanmongkol W, Matsumoto K, Watanabe H, Subhadhirasakul S, Sakai SI 1994. Antinociceptive and antipyretic effects 
of alkaloids extracted from the stem bark of Hunteria zeylanica. Biol Pharm Bull 17: 1345-1350.

Van den Dool H, Kratz PDJA 1963. Generalization of the retention index system including linear temperature programmed gas-liquid partition chromatography. $J$ Chromatog 11 : 463-471.

Veldkamp JF 1999. A revision of Chrysopogon Trin. including Vetiveria Bory (Poaceae) in Thailand and Malesia with notes on some other species from Africa and Australia. Austrobaileya 5: 503-533.

Vinegar R, Schreiber W, Hugo R 1969. Biphasic development of carrageenan edema in rats. J Pharmacol Exp Ther. 166: 96-103.

Wei ET, Kiang JG, Buchan P, Smith TW 1986. Cotticotrop in releasing factor inhibits neurogenic plasma extravasation in the rat paw. J Pharmacol Exp Ther 238: 783-787.

Weyerstahl P, Weyerstahl H, Splittgerber U, Wolf D 2000a. Analysis of the polar fraction of Haitian vetiver oil.
Flavour Fragr J 15: 153-173.

Weyerstahl P, Marschall H, Splittgerber U, Wolf D, Surburg H 2000b. Constituents of Haitian vetiver oil. Flavour Frag J 15: 395-412.

Winter CA, Riseley EA, Nuss GW 1962. Carrageenan-induced edema in the hind paw of the rats as an assay for antiinflammatory drugs. Proc Soc Exp Biol Med 111: 544547.

\section{*Correspondence}

Adriano Antunes de Souza Araújo

Departamento de Fisiologia, Curso de Farmácia, Universidade Federal de Sergipe

Av. Marechal Rondon sn, 49100-000, São Cristóvão-SE, Brazil adriano.antunes@pq.cnpq.br

Tel: +55 7921056841

Fax: +55 7921056827 